\title{
Adsorption of 3-Chloroaniline on Potato Skin in Aqueous Solution
}

\author{
Nidhal S. Mohammed, ${ }^{1}$ T. H. Flowers, ${ }^{2}$ and H. J. Duncan ${ }^{2}$ \\ ${ }^{1}$ School of Chemistry, University of Zakho, Zakho, Kurdistan Region, Iraq \\ ${ }^{2}$ School of Chemistry, University of Glasgow, Joseph Black Building, Glasgow G12 8QQ, UK
}

Correspondence should be addressed to Nidhal S. Mohammed; nidhalsher@yahoo.com

Received 24 March 2016; Revised 22 June 2016; Accepted 23 June 2016

Academic Editor: Kaustubha Mohanty

Copyright (C) 2016 Nidhal S. Mohammed et al. This is an open access article distributed under the Creative Commons Attribution License, which permits unrestricted use, distribution, and reproduction in any medium, provided the original work is properly cited.

\begin{abstract}
The adsorption behaviour of aromatic amine 3-chloroaniline (3-CA) from aqueous solution on fresh potato skin was investigated. A series of batch experiments were conducted under different experimental conditions of contact time, 3-chloroaniline concentration, weight of potato skin, $\mathrm{pH}$, temperature, and ionic strength using RP-HPLC analysis. Adsorption equilibrium of 3-chloroaniline at concentration of $10 \mu \mathrm{g} / \mathrm{mL}$ on $1 \mathrm{~g}$ weight of chopped potato skin was achieved in 24 hours. Using different varieties of potato skin showed that the adsorption of 3-CA on Nicola variety is higher compared to Sante and Maris Peer varieties. Adsorption on potato skin was found to be generally higher compared to cortex and pith tissues. Analysis of adsorption isotherm shows that equilibrium data was fitted to Freundlich model $\left(R^{2}=0.977\right)$. Maximum adsorption capacities of 3-chloroaniline were found in the $\mathrm{pH}$ range from 3 to 9, whereas low adsorption quantities were found in high acidic and high basic solutions ( $\mathrm{pH} 2$ and $\mathrm{pH} 13$, resp.). Adsorption capacity increased with an increase in temperature from $4^{\circ} \mathrm{C}$ to $30^{\circ} \mathrm{C}$ but decreased with further increase of temperature to $40^{\circ} \mathrm{C}$. Testing the ionic strength showed that increasing the concentration of electrolyte reduces the adsorption efficiency. This study indicated that the fresh potato skin (without any treatment) is possible to use as a new adsorbent for removal of 3-chloroaniline from industrial waste water.
\end{abstract}

\section{Introduction}

The concentration of chlorinated aniline in the environmental samples is continuously increased due to the degradation of various pesticides and frequent use in variety of industries in several processes as reagents or intermediates in the manufacture of pigments, pharmaceuticals, dyes, rubber, cosmetics, and medicines [1-5]. These aromatic amines compounds may be hazardous to plant, animals, and human for long duration even at very low concentration $(\mu \mathrm{g} / \mathrm{L})$ and are suspected to be carcinogenic and highly toxic to human beings and aquatic life [6]. Due to this anxiety, the US Environmental Protection Agency (EPA) included most of these substances in list of priority pollutants [7].

Nowadays, the awareness of increasing water pollution and the use of removal of chlorinated amines from wastewater are so important. Adsorption is one process applied to wastewater treatment due to high efficiency, environmental friendliness, low cost, insensitivity to toxic substances, and the possibility of recycling the materials [8].

3-Chloroaniline is one of the chlorinated aromatic amines, and it is not only distributed through the industrial production but also formed as a product of thermal and microbial degradation of application potato sprout inhibitor chlorpropham (CIPC) in potato stores [9-13]. In reviewing the literature, adsorption studies of 3-chloroaniline have been investigated in aqueous solutions on various adsorbents such as soil [14], chelating resin [2], and clays $[3,6,15,16]$.

Potato peel is disposed as a waste that lags about $80-$ 100 grams from every $1 \mathrm{~kg}$ of potato crop. Activated carbons prepared from potato peels can be used as adsorbent to remove most of contaminants from aqueous solutions and wastewaters such as heavy metals [17-19], dyes [20-22], and phenolic compounds $[23,24]$.

The novelty of the present research is to examine the adsorption efficiency of 3-CA on fresh potato skin 
as adsorbent (without any treatment and modifying with chemicals). This study accords with our earlier observations that showed difficult extraction of 3-CA from potato peel [25]. In reviewing the literature, several investigations have been reported on the fate of chloroaniline compounds in the plants indicating bound or nonextractable residues of these compounds [26-28].

In this study, high performance liquid chromatography (HPLC) was used, which is one of the most common techniques for the separation and determination of chlorinated aniline in environmental samples $[3,7]$.

\section{Materials and Methods}

2.1. Standards. Analytical grade reagent of 3-chloroaniline (99\%) was purchased from Sigma-Aldrich Chemie GmbH (Germany). The concentration of stock solution of 3-CA was chosen to be below its solubility's $\left(5400 \mu \mathrm{g} / \mathrm{mL}\right.$ at $\left.20^{\circ} \mathrm{C}\right)$ in water. For the preparation of stock aqueous solution of $5000 \mu \mathrm{g} / \mathrm{mL}$ of $3-\mathrm{CA}$ in water, an accurate weight of $0.5 \mathrm{~g}$ was weighted and dissolved in water in a $100 \mathrm{~mL}$ volumetric flask. The solution was noticed after a few minutes of mixing on the magnetic stirrer to be completely dissolved. However, to ensure complete dissolution of 3-CA solution, it was stirred for 24 hours using a magnetic stirrer in an incubator (LMS LTD Cooled Incubator, model number 303) at $20^{\circ} \mathrm{C}$ temperature. Detailed examination of solubility of 3-CA in aqueous solution showed no significant difference between preparation of 3-CA in water and its preparation in methanol [25].

Working solutions were prepared from the stock solution and stored in the fridge at $4^{\circ} \mathrm{C}$. The water used for preparation of the standards and the mobile phase was supplied from an ELGA PURELAB Option deionizer model LA613.

2.2. HPLC Analysis. The HPLC system used comprised a Gilson ${ }^{\circledR} 234$ autosampler, Cecil 1100 Series pump, Phenomenex $^{\circledR}$ Security Guard ${ }^{\mathrm{TM}}$ (part number KJO-4282) guard column with analytical column Phenomenex (ODS-2 $250 \mathrm{~mm} \times 4.6 \mathrm{~mm} 5 \mu \mathrm{m}$ SphereClone), and a Thermo Separation Spectra Series UV100 detector coupled with Dionex PeakNet software. A column oven (LaChrom, Merck L-7350) was connected with a cooling system (Techne, Tecam ${ }^{\circledR} \mathrm{R} 4-2$ ) to control the column at $20^{\circ} \mathrm{C}$ temperature. An isocratic method was employed using mobile phase prepared from methanol (HPLC grade from Fisher Scientific, UK) and water $(55: 45 \mathrm{v} / \mathrm{v} \%)$. The water used for preparation of the mobile phase was filtered through a Supor ${ }^{\circledR} 20047 \mathrm{~mm}, 0.2 \mu \mathrm{m}$ membrane filter. The mobile phase was degassed for at least 20 minutes using an ultrasonic bath (Camlab CamSonix C425). HPLC analysis was performed at a detection wavelength of $210 \mathrm{~nm}$, pump flow rate of $1.5 \mathrm{~mL} / \mathrm{min}$ with an injection volume of $20 \mu \mathrm{L}$, and chromatographic run for 10 minutes.

2.3. Batch Adsorption Experiments. Batch adsorption studies of 3-CA were performed by spiking of triplicates of chopped potato skin $(0.5 \times 0.5 \mathrm{~cm})$ with aqueous solution of 3 -CA

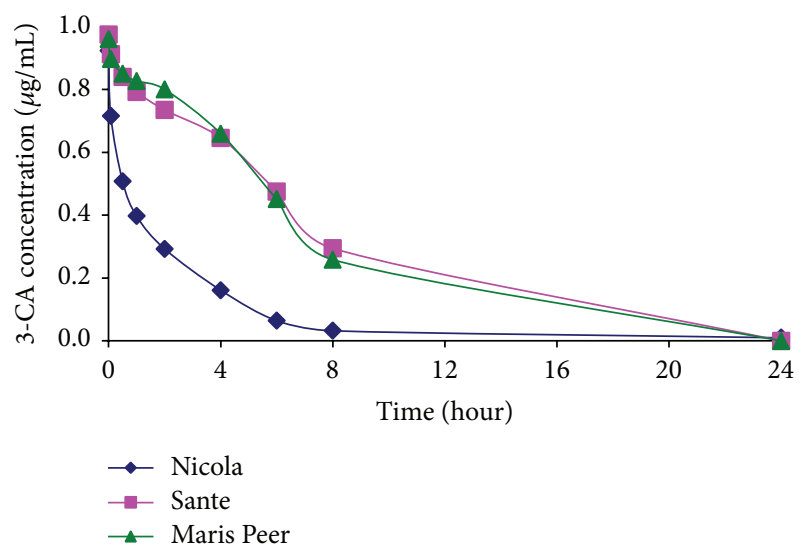

FIgURE 1: Adsorption of 3-CA on different varieties of potato skin in an aqueous solutions (conditions: $C_{i}, 1 \mu \mathrm{g} / \mathrm{mL} ; \mathrm{pH}$, 7; weight of chopped potato skin, $1 \mathrm{~g}$; temperature, $20^{\circ} \mathrm{C}$; speed of shaker, $100 \mathrm{rev} / \mathrm{min})$.

solution in a $100 \mathrm{~mL}$ screw jar. The spiked skin was agitated for contact time using an orbital incubator (Gallenkamp orbital incubator cooled) which is set up at $20^{\circ} \mathrm{C}$ and $100 \mathrm{rev} / \mathrm{min}$. Sample from the solution was transferred into HPLC vial using $2 \mathrm{~mL}$ syringe and filter disk syringe $(17 \mathrm{~mm})$ and the remaining concentration of $3-\mathrm{CA}$ in the aqueous solution was determined by injecting $20 \mu \mathrm{L}$ into HPLC. The remaining concentration of 3-CA in the sample solution is expressed on the concentration in the solution at equilibrium state $\left(C_{e}\right)$. The amount adsorbed $(Q)$ in $\mu \mathrm{g}$ of 3-chloroaniline per $\mathrm{g}$ of potato skin and the adsorption efficiency (\%) were calculated according to the following equations:

$$
\begin{aligned}
\operatorname{adsorption} \operatorname{capacity}(Q) & =\frac{V}{m}\left(C_{i}-C_{e}\right), \\
\operatorname{adsorption} \text { efficiency }(\%) & =\frac{\left(C_{i}-C_{e}\right)}{C_{i}} \times 100,
\end{aligned}
$$

where $V$ is the volume $(\mathrm{mL})$ of 3-chloroaniline solution used, $m$ is the weight of the potato skin $(\mathrm{g})$, and $C_{i}$ and $C_{e}$ are the initial and equilibrium concentrations of 3chloroaniline solution $(\mu \mathrm{g} / \mathrm{mL})$, respectively. $Q$ values were then plotted against their corresponding $C_{e}$ values to construct the adsorption isotherms [29]. Different parameters including the contact time, adsorption isotherm, adsorbent skin amount, $\mathrm{pH}$, temperature, and ionic strength were investigated.

\section{Results and Discussion}

3.1. Different Potato Varieties. Adsorption of 3-CA onto different potato skin varieties was investigated. In terms of decreasing the initial concentration of 3-CA as a faction with contact time, Figure 1 shows high adsorption of 3CA on Nicola variety compared to Sante and Maris Peer varieties. Complete adsorption of 3-CA onto potato skin was shown after 24 hours with all three potato varieties. The adsorption process is likely to involve many of the attraction 


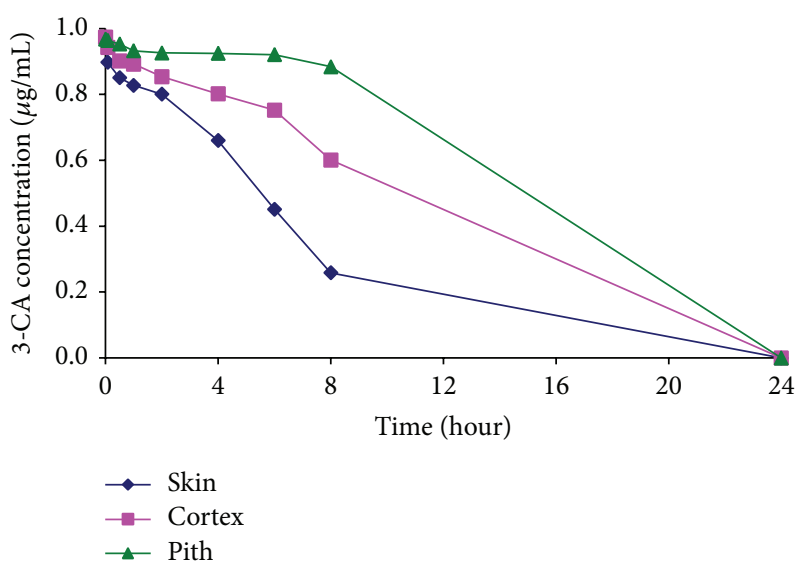

FIgURE 2: Adsorption of 3-CA on different layers of potato (Maris Peer variety) in an aqueous solution (conditions: $C_{i}, 1 \mu \mathrm{g} / \mathrm{mL} ; \mathrm{pH}$, 7 ; weight of chopped potato sample, $1 \mathrm{~g}$; temperature, $20^{\circ} \mathrm{C}$; speed of shaker, $100 \mathrm{rev} / \mathrm{min}$ ).

forces that lead to high adsorption capacity of 3-CA. The mechanisms of adsorption processes may involve Van der Waals forces, electrostatic interaction, hydrogen and covalent bonding, ligand exchange, and hydrophobic bonding or partitioning which are the most important types of the interactive forces between adsorbent and adsorbed material [30]. The occurrence of these mechanisms depends on the nature of the functional group of both adsorbed material and adsorbate surface; however, not all these mechanisms may occur simultaneously. The difference in the adsorption extent onto these three different potato skin varieties at the first 8 hours can be explained by the fact that potato varieties have different characteristics including moisture, texture, nutrient contents, and skins composition [31,32].

3.2. Different Layers of the Potato Tuber. Potato tubers are composed of distinct tissues: mainly the skin (the coloured and the outer layer of potato tuber), cortex (the area under skin), and pith, which is the more translucent and wetter part in the centre of the potato tuber [33]. Investigation of the adsorption of 3-CA from aqueous solution onto these three layers from potato showed results of higher adsorption on the skin compared to cortex and pith as can be seen in Figure 2. It seems possible that these different adsorption results at the first 8 hours are due to the difference in the composition of these layers within the potato tuber. However, all 3-CA was adsorbed at 24 hours with all layers indicating high adsorption affinity between 3-CA and potato tuber layers.

\subsection{Effect of Contact Time on Adsorption of 3-CA on Potato} Skin. The effect of contact time was studied at different intervals $(0,0.08,0.5,1,2,4,6,8,24$, and 48 hours) to determine the remaining concentration of $3-\mathrm{CA}$ in the solution until an equilibrium was reached, with no further uptake of adsorption of 3-CA on the skin. The initial concentration of 3-CA was found to decrease with increase in contact time reaching equilibrium after 24 hours (Figure 3). The result can be interpreted that the adsorption of 3-CA onto

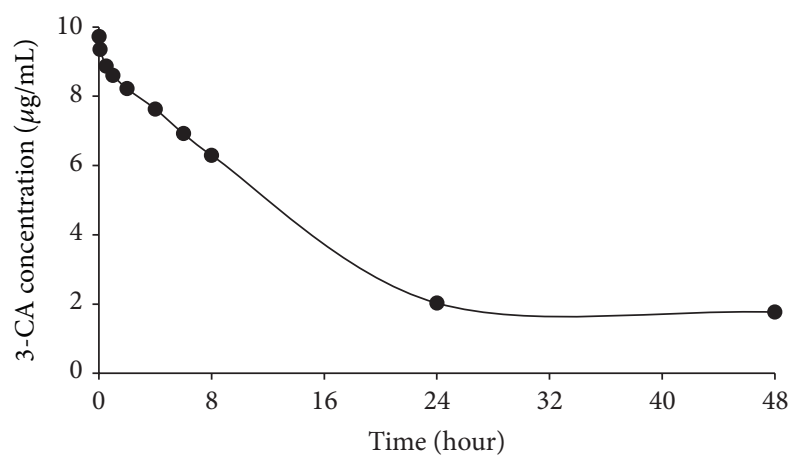

FIGURE 3: The equilibrium time of adsorption of 3-CA on potato skin (Nicola variety) in an aqueous solution (conditions: $C_{i}, 10 \mu \mathrm{g} / \mathrm{mL}$; $\mathrm{pH}, 7$; weight of chopped potato skin, $1 \mathrm{~g}$; temperature, $20^{\circ} \mathrm{C}$; speed of shaker, $100 \mathrm{rev} / \mathrm{min}$ ).

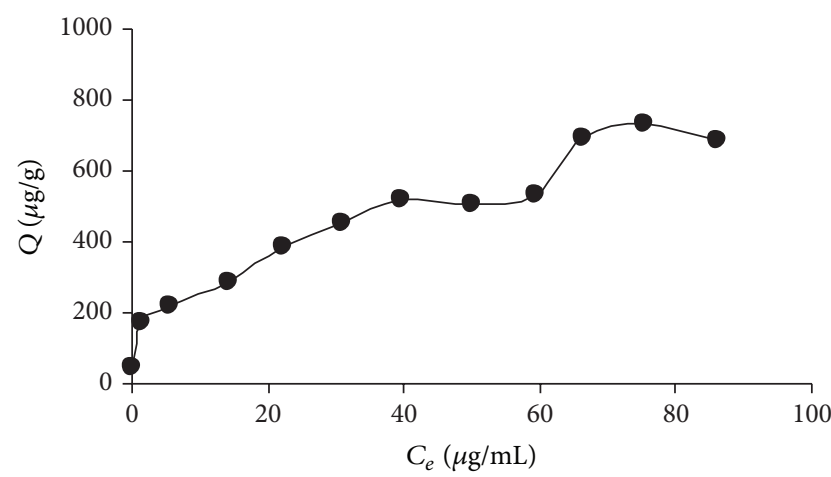

FIgUre 4: Adsorption isotherm of 3-CA onto potato skin of Maris Peer variety (conditions: $\mathrm{pH}, 7$; weight of chopped potato skin, $1 \mathrm{~g}$; contact time, 24 hours; temperature, $20^{\circ} \mathrm{C}$; speed of shaker, $100 \mathrm{rev} / \mathrm{min}$ ).

potato skin occurs rapidly at the beginning of contact times due to the fact that a large number of surface sites are available on the potato skin. Then the adsorption became lower followed by no further adsorption when all these sites are occupied. Based on these results, 24 hours was selected as a base for equilibrium time for further experiments in this study.

3.4. Adsorption Isotherm. The aim of the adsorption isotherm is to reveal the specific relation between the amount adsorbed onto the surface and the equilibrium concentration of the adsorbate in the solution at constant temperature; it should be fitted into suitable isotherm models [29]. The adsorption isotherm of 3-CA on the potato skin was studied at different concentrations $(1,5,10,20$, $30,40,50,60,70,80,90$, and $100 \mu \mathrm{g} / \mathrm{mL}$ ). The general shape of the adsorption isotherm was found as shown in Figure 4.

The resulting isotherm indicates that the potato skin has a greater ability to adsorb 3-CA. The isotherm result was analysed using Langmuir and Freundlich isotherms. The result is more in agreement with Freundlich isotherm as 


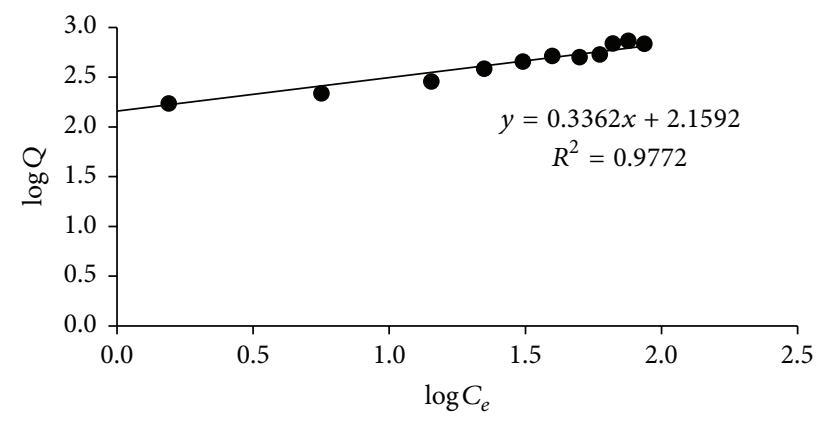

FIGURE 5: Freundlich isotherm plot for the adsorption of 3-CA on Maris Peer skin (conditions: $\mathrm{pH}$, 7; weight of potato skin, $1 \mathrm{~g}$; contact time, 24 hours; temperature, $20^{\circ} \mathrm{C}$; speed of shaker, $100 \mathrm{rev} / \mathrm{min}$ ).

TABLE 1: Adsorption capacities of 3-chloroaniline on various adsorbents.

\begin{tabular}{lcc}
\hline Adsorbent & $\begin{array}{c}\text { Adsorption } \\
\text { capacity } \\
\left(\mathrm{mg} \mathrm{g}^{-1}\right)\end{array}$ & References \\
\hline Kaolinite KGa-1 & 0.006 & {$[15]$} \\
Na-montmorillonite SWy-1 & 0.003 & {$[15]$} \\
Activated halloysite & 0.180 & {$[16]$} \\
Fresh potato peel & 0.144 & Present study \\
\hline
\end{tabular}

shown in Figure 5. The Freundlich equation is described by the following linearized form:

$$
\log Q=\log K_{\mathrm{f}}+\left(\frac{1}{n}\right) \log C_{e}
$$

where $C_{e}$ is the equilibrium concentration $(\mu \mathrm{g} / \mathrm{mL}), Q$ is the amount adsorbed $(\mu \mathrm{g})$ per unit weight of adsorbent $(\mathrm{g})$, and $K_{\mathrm{f}}$ and $n$ are Freundlich constants, which represent adsorption capacity and adsorption intensity and are calculated from the intercept and slope. The Freundlich isotherm parameters along with $K_{\mathrm{f}}$ and $n$ were determined to be $144 \mu \mathrm{g} / \mathrm{g}$ and 3, respectively, with $R^{2}$ of 0.977 . Comparative $K_{\mathrm{f}}$ values for other adsorbents studied are given in Table 1. Generally, a greater value of $K_{\mathrm{f}}$ refers to a high adsorption capacity, whereas $n>1$ illustrates that the adsorbate is favorably adsorbed on the adsorbent $[29,34]$. Freundlich isotherm can be applied for nonideal adsorption on the heterogeneous surfaces when multilayer adsorption is formed $[29,35]$.

3.5. Effect of the Skin Weight on 3-CA Adsorption. The weight of the adsorbent is important factor for the adsorption efficiency and capacity of 3-chloroaniline. The effect of the weight of the potato skin on adsorption of 3-CA was studied. Five weights were selected $(1,3,5,7$, and $10 \mathrm{~g})$. The results in Figure 6 show that adsorption efficiency of 3-chloroaniline increases with the increase of potato skin weight, whereas the adsorption capacity decreases with the increase of potato skin. $1 \mathrm{~g}$ of potato skin was preferred as a best economical adsorbent weight in this study because of high adsorption capacity and adequate adsorption efficiency of 3-CA at this weight.

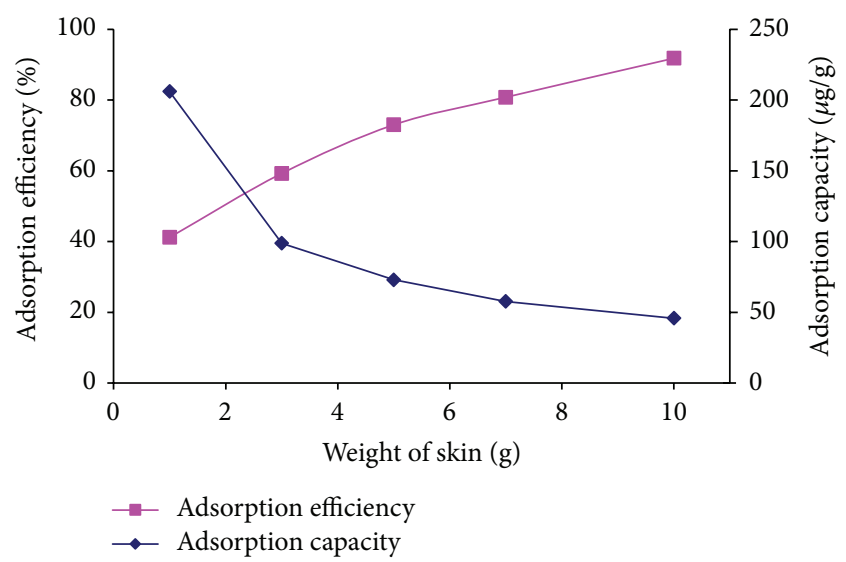

FIgURE 6: The effect of the adsorbent skin weight on 3-CA adsorption efficiency and capacity (conditions: $C_{i}, 10 \mu \mathrm{g} / \mathrm{mL} ; \mathrm{pH}, 7$; contact time, 24 hours; temperature, $20^{\circ} \mathrm{C}$; speed of shaker, $100 \mathrm{rev} / \mathrm{min}$ ).

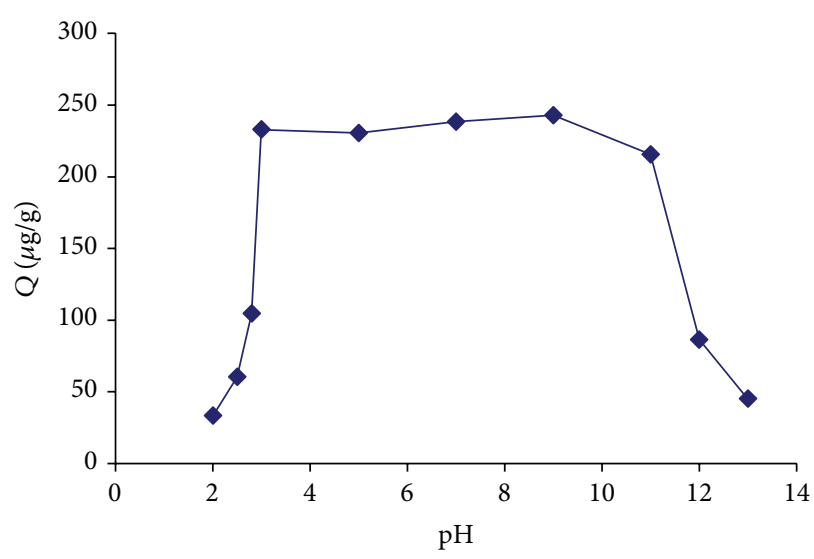

FIGURE 7: The effect of $\mathrm{pH}$ on the adsorption of 3-chloroaniline on potato skin (conditions: $C_{i}, 10 \mu \mathrm{g} / \mathrm{mL}$; weight of potato skin, $1 \mathrm{~g}$; contact time, 24 hours; temperature, $20^{\circ} \mathrm{C}$; speed of shaker, $100 \mathrm{rev} / \mathrm{min}$ ).

3.6. Effect of $p H$. The adsorption of 3-CA in aqueous solution on potato skin was examined by optimizing the effect of $\mathrm{pH}$ at a broad range of 2-13 using either acetic acid or sodium hydroxide solutions, while deionized water was used to provide $\mathrm{pH}$ 7. Figure 7 shows that the high acidity and alkalinity produce a lower adsorbed quantity of 3-chloroaniline. The adsorption capacities of 3-chloroaniline sharply increase with increasing $\mathrm{pH}$ values from 2 to 3 and then remained constant up to 9 , followed by decreasing with increasing $\mathrm{pH}$ from 9 to 13. The effective $\mathrm{pH}$ values that gave high adsorption quantity of 3-chloroaniline were 7 and 9. $\mathrm{pH} 7$ was applied in further studies.

The protonation of the functional groups of both adsorbed materials and adsorbents plays important role of $\mathrm{pH}$ effect on the adsorption process [36]. Adsorption of $\mathrm{H}^{+}$and $\mathrm{OH}^{-}$ions on surface of material changes the surface charge of material (zeta potential value). At low $\mathrm{pH}$, the competition between $\mathrm{H}^{+}$and 3-chloroaniline limits the uptake efficiency. The high concentration of $\mathrm{H}^{+}$in solution 


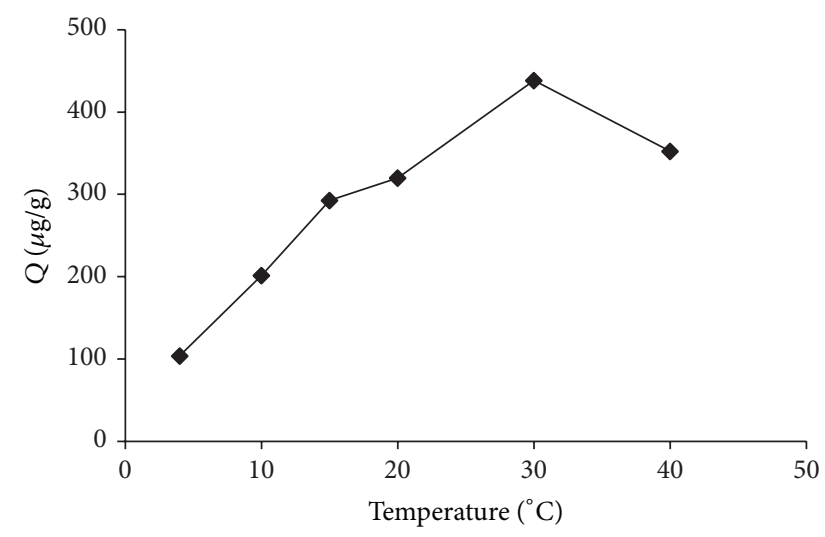

FIgURE 8: The effect of temperature on the adsorption of 3chloroaniline on potato skin (conditions: $C_{i}, 10 \mu \mathrm{g} / \mathrm{mL}$; $\mathrm{pH}, 7$; weight of potato skin, $1 \mathrm{~g}$; contact time, 24 hours; speed of shaker, $100 \mathrm{rev} / \mathrm{min}$ ).

may attack the functional groups of potato skin composition (increases the zeta potential value); consequently, active sites of the potato skin become less available to adsorb 3chloroaniline. While increasing the $\mathrm{pH}$ from 2 to 3 , the amine group of 3-CA may become ionized ( $K_{a}=3.5$ ) which leads to 3 -chloroanilinium cation becoming adsorbed on potato skin due to attraction forces between both. Since the adsorption increases with $\mathrm{pH}$ and then remains constant in the $\mathrm{pH}$ range of 3-9, the active sites on the potato skin bind 3-CA very well perhaps by ion exchange or complexation processes [37]. Another possibility is that 3-CA can be adsorbed as neutral molecule in the $\mathrm{pH}$ solution of 3-9 by hydrogen bonding with abundant functional groups on potato skin (e.g., $\mathrm{OH}$ and $\mathrm{COOH}$ ) [30]. Increasing $\mathrm{pH}$ values beyond 9 decreased the adsorption capacities due to the fact that the amine group of chloroaniline is less positive [36]. This low adsorption may also be attributed to the competing of the high concentration of $\mathrm{OH}^{-}$(decreases the zeta potential value) with 3-chloroaniline to form hydrogen bond with water molecule's presence in potato skin.

3.7. Temperature Effect. Temperature parameter has a critical role in adsorption processes. According to the adsorption theory, adsorption process decreases when the temperature increases. Molecules which were adsorbed earlier on a surface have a tendency to be desorbed from the surface at elevated temperatures [38]. The effect of the temperature on adsorption process was studied. However, a different trend was noticed in case of adsorption of 3-CA on potato skin at various temperatures $\left(4,10,15,20,30\right.$, and $\left.40^{\circ} \mathrm{C}\right)$. The adsorption increased from $4^{\circ} \mathrm{C}$ to $30^{\circ} \mathrm{C}$ but further increase of temperature to $40^{\circ} \mathrm{C}$ decreases the adsorption as shown in Figure 8. Increasing the temperature to $30^{\circ} \mathrm{C}$ indicates an increase in molecular motion and decreases the viscosity permitting 3-CA to penetrate easily into the potato skin surface and interact with active sites leading to more adsorption. The decrease of adsorption above $30^{\circ} \mathrm{C}$ may be attributed to collapse of hydrogen bond or electrostatic forces of 3-CA on potato skin.

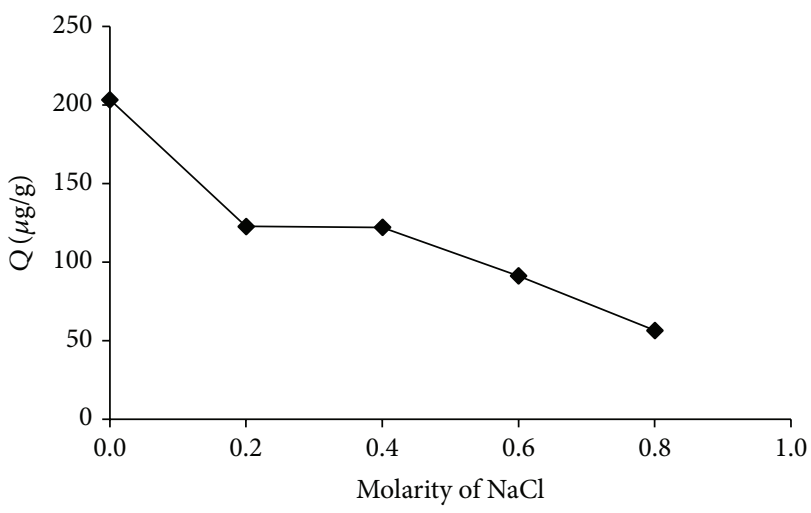

Figure 9: The effect of ionic strength on the adsorption of 3chloroaniline on potato skin (conditions: $C_{i}, 10 \mu \mathrm{g} / \mathrm{mL} ; \mathrm{pH}$, 7; weight of potato skin, $1 \mathrm{~g}$; temperature, $20^{\circ} \mathrm{C}$; contact time, 24 hours; speed of shaker, $100 \mathrm{rev} / \mathrm{min})$.

3.8. Ionic Strength. The effect of ionic strength on the adsorption of 3-CA on potato skin was investigated by the presence of electrolyte of $\mathrm{NaCl}$ at varying concentrations $(0$, $0.2,0.4,0.6$, and $0.8 \mu \mathrm{g} / \mathrm{mL}$ ) in 3 -CA solutions. The amount adsorbed of 3-CA was found to be decreased with increased $\mathrm{NaCl}$ concentration as shown in Figure 9. This decrease in adsorption may be due to the fact that the external electrolyte either decreases the hydrophobic nature of 3-CA molecules in the solution or increases the electrostatic interaction between their ions in the solution and polar molecules of 3-CA. The adsorption is sensitive to changes in the concentration of the supporting electrolyte if the driving force of the adsorption is the electrostatic interaction [39].

\section{Conclusion}

This work clearly indicates the adsorption of 3-CA to potato skin is a relatively rapid equilibrium process and is strongly dependent on the contact time, initial 3-CA concentration, potato skin weight, $\mathrm{pH}$, temperature, and ionic strength. Contact time of 24 hours is sufficient to adsorb all of 3CA at concentration of $1 \mu \mathrm{g} / \mathrm{mL}$ on different potato skin varieties and different potato layers. $\mathrm{p} K_{a}$ of 3-chloroaniline is 3.52 , indicating that this basic compound will primarily be present as nonionic organic base. It is therefore sensible to hypothesize that specific interactions such as hydrogen bonding or Van der Waals forces may play important role in the adsorption mechanism of neutral molecules and weak base compounds $[6,15]$. The adsorption process follows Freundlich isotherm indicating that adsorption of 3-CA on potato skin is favorable. This study revealed that potato skins which are abundantly available as solid waste can be used as new adsorbent to remove toxic chlorinated aniline from industrial effluents.

\section{Competing Interests}

The authors declare that there are no competing interests regarding the publication of this paper. 


\section{Acknowledgments}

This research was supported by School of Chemistry at University of Glasgow, UK. Particularly, Nidhal S. Mohammed would like to thank Dr. T. H. Flowers and H. J. Duncan for their patient guidance, support, and encouragement.

\section{References}

[1] A. Di Corcia, A. Costantino, C. Crescenzi, and R. Samperi, "Quantification of phenylurea herbicides and their free and humic acid-associated metabolites in natural waters," Journal of Chromatography A, vol. 852, no. 2, pp. 465-474, 1999.

[2] M. Uçan and A. Ayar, "Sorption equilibria of chlorinated anilines in aqueous solution on resin-bound cobalt ion," Colloids and Surfaces A: Physicochemical and Engineering Aspects, vol. 207, no. 1-3, pp. 41-47, 2002.

[3] S. Angioi, S. Polati, M. Roz, C. Rinaudo, V. Gianotti, and M. C. Gennaro, "Sorption studies of chloroanilines on kaolinite and montmorillonite," Environmental Pollution, vol. 134, no. 1, pp. 35-43, 2005.

[4] H.-M. Hwang, D. McCullum, and L. Slaughter, "Phototransformation of 2,4-dichloroaniline in a surface freshwater environment: effects on microbial assemblages," Bulletin of Environmental Contamination and Toxicology, vol. 60, no. 1, pp. 81-87, 1998.

[5] D. D. Kaufman and J. Blake, "Microbial degradation of several acetamide, acylanilide, carbamate, toluidine and urea pesticides," Soil Biology and Biochemistry, vol. 5, no. 3, pp. 297-308, 1973.

[6] W. Matthes and G. Kahr, "Sorption of organic compounds by Al and Zr-hydroxy-intercalated and pillared bentonite," Clays and Clay Minerals, vol. 48, no. 6, pp. 593-602, 2000.

[7] J.-F. Peng, J.-F. Liu, G.-B. Jiang, C. Tai, and M.-J. Huang, "Ionic liquid for high temperature headspace liquid-phase microextraction of chlorinated anilines in environmental water samples," Journal of Chromatography A, vol. 1072, no. 1, pp. 3-6, 2005.

[8] Y. Zhao, E. Abdullayev, A. Vasiliev, and Y. Lvov, "Halloysite nanotubule clay for efficient water purification," Journal of Colloid and Interface Science, vol. 406, no. 15, pp. 121-129, 2013.

[9] B. L. Worobey and W.-F. Sun, "Isolation and identification of chlorpropham and two of its metabolites in potatoes by GCMS," Chemosphere, vol. 16, no. 7, pp. 1457-1462, 1987.

[10] T. Nagayama and K. Kikugawa, "Influence of frying and baking on chlorpropham residue," Japanese Journal of Toxicology and Environmental Health, vol. 38, no. 1, pp. 78-83, 1992.

[11] P. Verhagen, L. De Gelder, S. Hoefman, P. De Vos, and N. Boon, "Planktonic versus biofilm catabolic communities: importance of the biofilm for species selection and pesticide degradation," Applied and Environmental Microbiology, vol. 77, no. 14, pp. 4728-4735, 2011.

[12] D. D. Kaufman and P. C. Kearney, "Microbial degradation of isopropyl-N-3-chlorophenylcarbamate and 2-chloroethyl-N-3chlorophenylcarbamate," Applied Microbiology, vol. 13, no. 3, pp. 443-446, 1965.

[13] P. C. Kearney and D. D. Kaufman, "Enzyme from soil bacterium hydrolyzes phenylcarbamate herbicides," Science, vol. 147, no. 3659, pp. 740-741, 1965.

[14] C. A. M. Van Gestel and W.-C. Ma, "Development of QSAR's in soil ecotoxicology: earthworm toxicity and soil sorption of chlorophenols, chlorobenzenes and chloroanilines," Water, Air, and Soil Pollution, vol. 69, no. 3-4, pp. 265-276, 1993.

[15] S. Polati, F. Gosetti, V. Gianotti, and M. C. Gennaro, "Sorption and desorption behavior of chloroanilines and chlorophenols on montmorillonite and kaolinite," Journal of Environmental Science and Health, Part B: Pesticides, Food Contaminants, and Agricultural Wastes, vol. 41, no. 6, pp. 765-779, 2006.

[16] B. Szczepanik, P. Słomkiewicz, M. Garnuszek, and K. Czech, "Adsorption studies of chlorpropham and 3-chloroaniline on chemically activated halloysite," Journal of Chemistry and Chemical Engineering, vol. 8, no. 1, pp. 626-634, 2014.

[17] M. A. Abdullah and A. G. D. Prasad, "Kinetics and equilibrium studies for the biosorption of $\mathrm{Cr}(\mathrm{VI})$ from aqueous solutions by potato peel waste," International Journal of Chemical Engineering Research, vol. 1, no. 2, pp. 51-62, 2009.

[18] T. Aman, A. A. Kazi, M. U. Sabri, and Q. Bano, "Potato peels as solid waste for the removal of heavy metal copper(II) from waste water/industrial effluent," Colloids and Surfaces B: Biointerfaces, vol. 63, no. 1, pp. 116-121, 2008.

[19] A. G. El-Said, N. A. Badawy, and A. Abd El Pasir, "Comparison of synthetic and natural adsorbent for sorption of $\mathrm{Ni}$ (II) ions from aqueous solution," Nature and Science, vol. 8, no. 11, pp. 86-94, 2010.

[20] E.-K. Guechi and O. Hamdaoui, "Sorption of malachite green from aqueous solution by potato peel: kinetics and equilibrium modeling using non-linear analysis method," Arabian Journal of Chemistry, vol. 4, no. 3, pp. 243-260, 2011.

[21] A. Maleki, H. Daraei, F. Khodaei, K. Bayazid-Aghdam, R. Rezaee, and A. Naghizadeh, "Investigation of potato peelbased bio-sorbent efficiency in reactive dye removal: artificial neural network modeling and genetic algorithms optimization," Journal of Advances in Environmental Health Research, vol. 1, no. 1, pp. 21-28, 2013.

[22] I. Anastopoulos and G. Z. Kyzas, "Agricultural peels for dye adsorption: a review of recent literature," Journal of Molecular Liquids, vol. 200, no. 1, pp. 381-389, 2014.

[23] J. C. Moreno-Piraján and L. Giraldo, "Immersion calorimetry applied to the study of the adsorption of phenolic derivatives onto activated carbon obtained by pyrolysis of potato peel," Materials Express, vol. 2, no. 2, pp. 121-129, 2012.

[24] A. S. Joodi and M. N. Abbas, "Removal of phenol from aqueous solutions using potato peel," Australian Journal of Basic and Applied Sciences, vol. 8, no. 2, pp. 115-123, 2014.

[25] N. M. Sher Mohammed, Extraction and HPLC analysis of potato sprout suppressant chemicals [Ph.D. thesis], University of Glasgow, Glasgow, UK, 2012, http://theses.gla.ac.uk/3454/.

[26] P. Adrian, F. Andreux, R. Viswanathan, D. Freitag, and I. Scheunert, "Fate of anilines and related compounds in the environment. A review," Toxicological \& Environmental Chemistry, vol. 20-21, no. 1, pp. 109-120, 2008.

[27] H. M. Balba, G. G. Still, and E. R. Mansager, "Studies on bound residues of chloroanilines in plants," Abstracts of Papers of the American Chemical Society, vol. 174, no. 1, p. 14, 1977.

[28] G. G. Still, H. M. Balba, and E. R. Mansager, "Studies on the nature and identity of bound chloroaniline residues in plants," Journal of Agricultural and Food Chemistry, vol. 29, no. 4, pp. 739-746, 1981.

[29] H. Zheng, D. Liu, Y. Zheng, S. Liang, and Z. Liu, "Sorption isotherm and kinetic modeling of aniline on Cr-bentonite," Journal of Hazardous Materials, vol. 167, no. 1-3, pp. 141-147, 2009. 
[30] B. Gevao, K. T. Semple, and K. C. Jones, "Bound pesticide residues in soils: a review," Environmental Pollution, vol. 108, no. 1, pp. 3-14, 2000.

[31] H. F. Seefeldt, E. Tønning, L. Wiking, and A. K. Thybo, "Appropriateness of culinary preparations of potato (Solanum tuberosum L.) varieties and relation to sensory and physicochemical properties," Journal of the Science of Food and Agriculture, vol. 91, no. 3, pp. 412-420, 2011.

[32] E. Ortiz-Medina, V. Sosle, V. Raghavan, and D. J. Donnelly, “A method for intercultivar comparison of potato tuber nutrient content using specific tissue weight proportions," Journal of Food Science, vol. 74, no. 5, pp. S177-S181, 2009.

[33] J. A. Woolfe, The Potato in Human Diet, Cambridge University Press, Cambridge, UK, 1987.

[34] Ö. Tunç, H. Tanaci, and Z. Aksu, "Potential use of cotton plant wastes for the removal of Remazol Black B reactive dye," Journal of Hazardous Materials, vol. 163, no. 1, pp. 187-198, 2009.

[35] R. A. K. Rao, M. Ajmal, R. Ahmad, and B. A. Siddiqui, "Adsorption behaviour of some aromatic amines on pyrolusite and activated carbon and recovery of $\beta$ napthylamine from water sample," Environmental Monitoring and Assessment, vol. 68, no. 3, pp. 235-247, 2001.

[36] L. Guo, G. Li, J. Liu, P. Yin, and Q. Li, "Adsorption of aniline on cross-linked starch sulfate from aqueous solution," Industrial \& Engineering Chemistry Research, vol. 48, no. 23, pp. 1065710663, 2009.

[37] T. S. Anirudhan, L. Divya, and P. S. Suchithra, "Kinetic and equilibrium characterization of uranium(VI) adsorption onto carboxylate-functionalized poly(hydroxyethylmethacrylate)grafted lignocellulosics," Journal of Environmental Management, vol. 90, no. 1, pp. 549-560, 2009.

[38] M. Horsfall Jr. and A. I. Spiff, "Effects of temperature on the sorption of $\mathrm{Pb}^{2+}$ and $\mathrm{Cd}^{2+}$ from aqueous solution by Caladium bicolor (Wild Cocoyam) biomass," Electronic Journal of Biotechnology, vol. 8, no. 2, pp. 162-169, 2005.

[39] T. S. Anirudhan and M. Ramachandran, "Adsorptive removal of tannin from aqueous solutions by cationic surfactant-modified bentonite clay," Journal of Colloid and Interface Science, vol. 299, no. 1, pp. 116-124, 2006. 

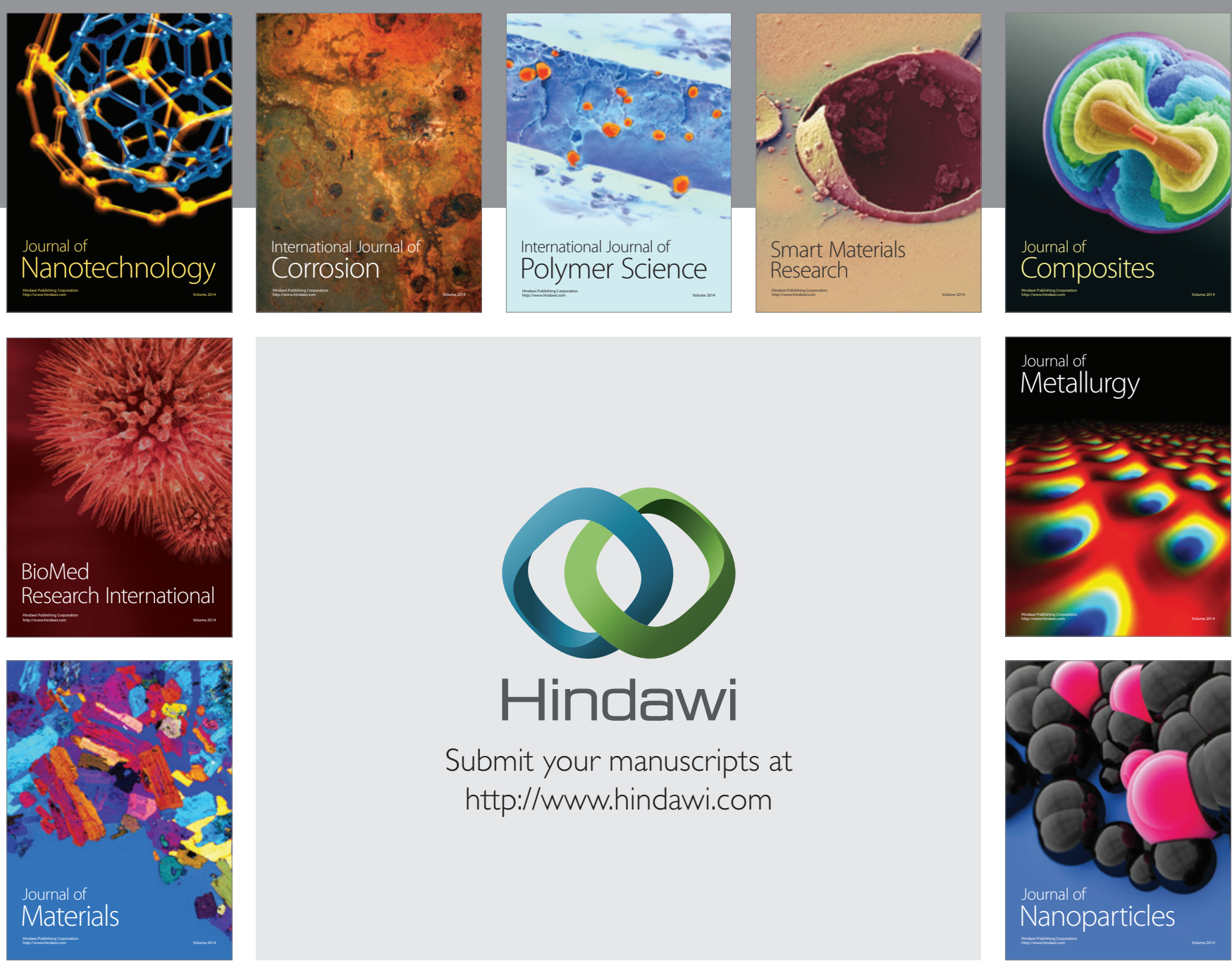

\section{Hindawi}

Submit your manuscripts at

http://www.hindawi.com

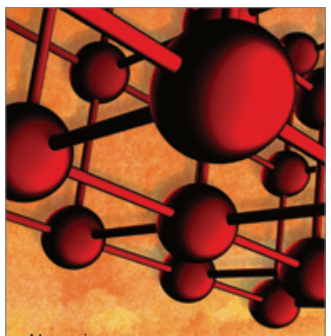

Materials Science and Engineering
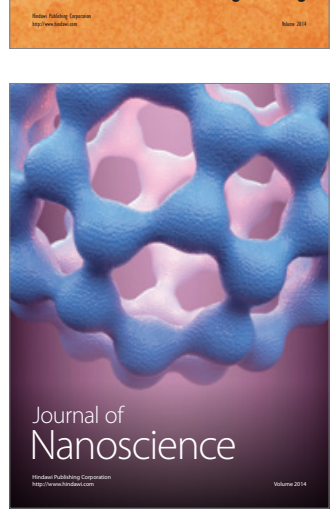
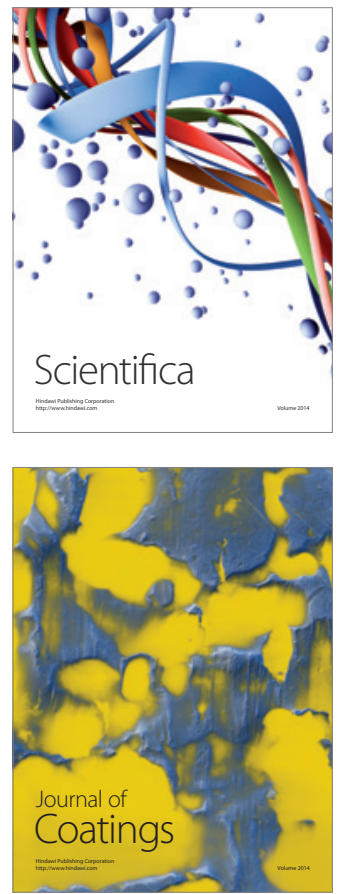
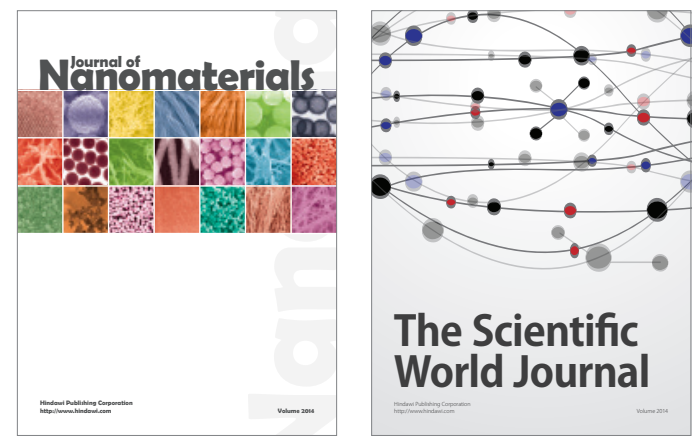

The Scientific World Journal
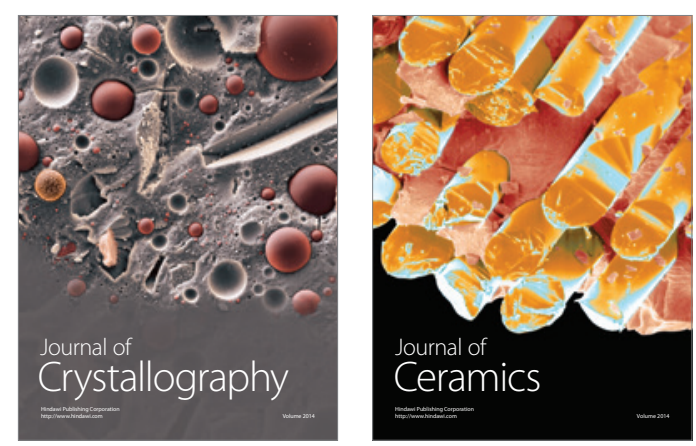
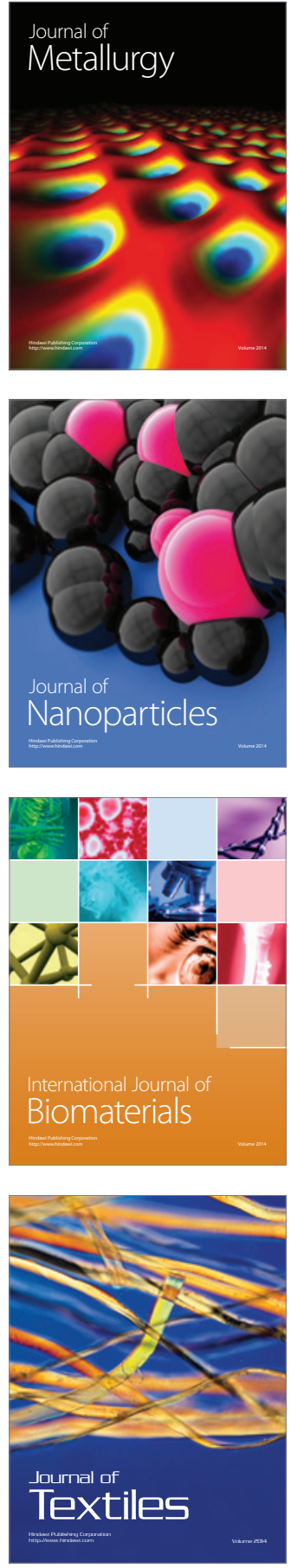